\title{
The content of macroelements in white mulberry (Morus alba L.) leaves
}

Dovilè Levickiené ${ }^{1}$,

Nijolè Vaitkevičien $\dot{e}^{1}$,

Elvyra Jariené ${ }^{1}$,

Romas Mažeika

${ }^{1}$ Institute of Agricultural and Food Sciences, Agronomy Faculty,

Aleksandras Stulginskis University,

Studentu St. 11, 53361 Akademija,

Kaunas District, Lithuania

Email:dovile.levickiene@asu.lt;

elvyra.jariene@asu.lt;

nijole.vaitkeviciene@asu.lt

${ }^{2}$ Agrochemical Laboratory

of the Lithuanian Research Centre

for Agriculture and Forestry,

Savanoriu Ave. 287,

50127 Kaunas, Lithuania

Email: romas.mazeika@lammc.lt
The aim of this study was to evaluate the agrochemical and biological quality indicators of soil and to determine the best harvest time to maximize the nutrient contents of white mulberry leaves (Morus alba L.) from two different cultivars. Mulberry leaves were analysed to determine the seasonal changes in the contents of $\mathrm{Ca}, \mathrm{K}, \mathrm{P}, \mathrm{Mg}$ and $\mathrm{S}$.

The study was carried out on 7-year-old mulberry trees belonging to Morus alba L. cultivated in an organic farm in the Kaunas District of Lithuania in 2016 and 2017. The soil agrochemical and biological indicators and mulberry leave samples were analysed two times during the tree vegetation period. The soil samples were collected in May and September (in the 2nd ten-day period) and leaves in June and September (in the 2nd ten-day period). The study revealed that a decreasing tendency for soil agrochemical indicators was observed throughout the entire period of growth of mulberry trees. At the end of the vegetation period the contents of nitrogen, available phosphorus and available potassium significantly decreased by $7.93,24.85$ and $25 \%$, respectively, compared with that taken in May. At the end of the mulberry tree vegetation period the microbial biomass and dehydrogenase activity in the soil significantly decreased, by 20.39 and $17.95 \%$, respectively, compared with that taken in the beginning of the vegetation period. The study revealed that harvest months had a statistically significant impact on the levels of the examined elements among the two Morus cultivars. It was found that the main macroelement in the leaves of both cultivars was $\mathrm{Ca}$ followed by K, P, Mg and S. However, the highest $\mathrm{Ca}, \mathrm{Mg}, \mathrm{P}$ and $\mathrm{S}$ contents in 'Turchanka' leaves increased with maturity. Importantly, the amount of macronutrients in the mulberry leaves varied in accordance with the cultivar and the harvest time.

These results can help farmers to select a cultivar and harvest time that would allow them to produce mulberry leaves with superior quality. Leaves collected from mulberry plants grown in Lithuania plantations may be used as a food supplement to help meet the recommended daily intakes of some macrominerals for adults.

Keywords: harvest time, macroelements, leaves, white mulberry

\section{INTRODUCTION}

In recent years, medicinal plants have been widely used in the treatment and prevention of diseases because they have a lower cost and fewer adverse effects in the body. Mulberry is a peren- nial, deep-rooted plant capable of thriving under diverse agro-climatic conditions. The white mulberry is the most cold-hardy of the three species Morus alba L., M. rubra L. and M. nigra L., although this varies from one clone to another (Ercisli, Orhan, 2007). 
The mulberry plant is one of the conventional herbs that have been used in medicine since time immemorial due to its chemical composition and pharmacological functions. Almost all parts of the mulberry plant are used in Chinese and Indian medicine and in the food industry (Yang et al., 2010). However, the most important feature of the white mulberry is its high value in terms of healthfulness. White mulberry, whose leaves are rich in phenolic compounds and flavonoids (Thabti et al., 2012), contain a wide range of macronutrients and trace elements, amino acids (Butt, 2008). Mulberry-leaf tea has increased in popularity over the past decades because of its antidepressant, antibacterial, hypoglycaemic and antioxidant effects (Jeszka-Skowron et al., 2017). All of these properties of the white mulberry show that this plant may be used multi-directionally.

Furthermore, some authors (Kim et al., 2014; Levickiene et al., 2017) have studied the quality, nutritional potentials and chemical compositions of different Morus species. Mineral elements play important roles in biological reactions and have structural functions. The mulberry leaves contain a variety of nutrients, including macroelements (Radojković et al., 2014; Srivastava et al., 2006). As reported by many authors, the chemical contents of plant (mulberry) leaves are influenced by many factors, such as genetics, environment, climatic conditions, irrigation, fertilizing and soil conditions (Chetri et al., 1999). Moreover, mineral contents in leaves also change seasonally (Marschner, 1995).

The purpose of the present investigation was to evaluate the agrochemical and biological quality indicators of soil, as well, for the first time, the effect of the harvest time on mineral elements in the leaves of white mulberry plants grown in Lithuania. These results will be important in order to select cultivars with higher mineral contents and strengthen the value-added uses of the leaf in nutritional, industrial and pharmaceutical applications. Mulberry leaves can be used as natural colour and flavour enhancers to improve the composition, functionality and quality of food products.

\section{RESEARCH METHODS AND CONDITIONS}

The white mulberry cultivars 'Plodovaja 3' and 'Turchanka' originate from Ukraine. The field ex- periment was conducted on an organic farm in the Kaunas District of Lithuania between 2016 and 2017.

The experimental plots were arranged in a randomized design with four replicates, each with 6 trees. The distance between rows was $5 \mathrm{~m}$ and the distance between mulberry trees was $4 \mathrm{~m}$. Trees were planted in 2010 and were not fertilized. Between the rows of mulberry trees white clover (Trifolium repens L.) was grown. The clover was cut and left on the soil as mulch. No diseases and pest control products were used in the experimental plots.

According to the data of the Kaunas Meteorological Station, the meteorological growing conditions in 2016 were favourable for mulberry vegetation because it was warm. In May compared to the Standard Climate Normal (SCN is the 30year average from 1981 to 2010), the precipitation amount was 1.15 times more. September was dry and warm. The May of 2017 was favourable for the growth of mulberry trees. The average air temperature was very close to the SCN, the precipitation amount was by $7.2 \mathrm{~mm}$ more compared to SCN. September was warm and very wet, and the precipitation amount was 1.6 times more compared to SCN.

Of both cultivars, in each replication of the treatment, composite soil samples were taken two times (in May and in September in the 2nd ten-day period) from 5 places from the arable layer $(0-20 \mathrm{~cm}$ depth) using an agrochemical auger. The samples were air-dried, crushed in a porcelain mortar and sieved with a $2 \mathrm{~mm}$ sieve. The soil samples were analysed for: the soil $\mathrm{pH}$ by a potentiometric method using a $\mathrm{pH}$-meter in $1 \mathrm{~N} \mathrm{KCl}$ extract (LST ISO 10390:2005), the total nitrogen $\%$ by the Kjeldal method, the available $\mathrm{P}_{2} \mathrm{O}_{5}$ concentration $\mathrm{mg} \mathrm{kg}^{-1}$ by the CAL method using a spectrophotometer Beckman DU-40, the available $\mathrm{K}_{2} \mathrm{O}$ concentration $\mathrm{mg} \mathrm{kg}^{-1}$ by the CAL method using a flame photometer Corning PC-410, the soil activity of dehydrogenase after the M. A. Tabatabai (1982) and M. Järvan (2014) methods (ISO/FDIS 23753-2) and the microbial biomass by the chloroform fumigationextraction method (ISO 14240-2:1997).

The leaves from each mulberry cultivar were manually collected representing the whole tree by collecting from four sides, under the same 
conditions once in June and September, in the 2 nd ten-day period.

The laboratory sample was made up of $60-70$ leaves from each tree. The leaves were frozen at $-35^{\circ} \mathrm{C}$, lyophilized using a freeze-drying plant sublimator $3 \times 4 \times 5$ (ZIRBUS Technology $\mathrm{GmbH}$, Bad Grund, Germany), ground into a fine powder for $1 \mathrm{~min}$ at $8000 \mathrm{rpm}$ in a laboratory mill (Grindomix GM 200, Retsch GmbH, Haan, Germany) and stored in an airtight container until further use. The chemical analyses of the mulberry leaves were conducted in the Agrochemical Research Laboratory of the Lithuanian Research Centre for Agriculture and Forestry.

Powdered samples of the mulberry leaves were transformed into solutions and analysed. Potassium $(\mathrm{K})$ and phosphorus $(\mathrm{P})$ were measured photometrically after wet digestion in sulphuric acid. Calcium $(\mathrm{Ca})$, magnesium $(\mathrm{Mg})$ and sulphur $(\mathrm{S})$ were determined by inductively coupled plasma atomic emission spectrometry (ICP-AES) after acid digestion in $\mathrm{HNO}_{3}: \mathrm{H}_{2} \mathrm{O}_{2}(5: 3, \mathrm{v} / \mathrm{v})$ in a microwave reaching $200^{\circ} \mathrm{C}$ after $20 \mathrm{~min}$. The solution was maintained at this temperature for $2 \mathrm{~h}$. The procedures were performed according to the standard method (LST EN 15510:2017).

Chemical analyses were performed in triplicate. The experimental data were statistically analysed with ANOVA tests using the Statistica software version 7.0 (StatSoft, USA). Averages of the research data were calculated, and the Tukey's HSD test $(p<0.05)$ was applied to estimate the statistical significance of the differences between the data.

\section{RESULTS AND DISCUSSION}

\section{Soil agrochemical and biological indicators}

Soil fertility is determined by the optimal regime of the major nutrients such as nitrogen, phosphorus and potassium. When these elements are in short supply in the soil, mulberry performs and yields poorly.

The results averaged over the two experimental years of the white mulberry cultivars 'Plodovaja 3' and 'Turchanka' agrochemical and biological indicators of the soil are shown in Table 1 . The data show that in the beginning of the mulberry trees vegetation period significantly higher contents of nitrogen, available phosphorus and available potassium in the soil were accumulated in May. At the end of the vegetation period the contents of nitrogen, available phosphorus and available potassium significantly decreased by $7.93,24.85$ and $25 \%$, respectively, compared with that taken in May (Table 1). In our experiment, during all mulberry trees vegetation period $\mathrm{pH}_{\mathrm{KCl}}$ was close to neutral acidity (6.41-6.81). From the mulberry trees vegetation beginning until the end of the season the contents of nutrients in the soil were decreasing because of the uptake by growing plants.

One of the most important and most accurate soil biological activity indicators are soil microbial biomass and soil enzyme activity. The increase in the biomass of microorganisms in the soil indicates that the capacity of microorganisms and the degradation of organic matter are higher. Also, this indicator is important for the assessment of organic matter deposits in the soil. Activity of dehydrogenase can show the characteristics of microbiological activity in the soil. The enzyme is active and reliably reflects the activity of active soil microorganisms. Our study showed that the amount of soil microbial biomass and dehydrogenase activity were significantly higher in the beginning of the mulberry tree vegetation (Table 1). A decreasing tendency for the soil microbial biomass and dehydrogenase activity has been observed throughout the entire period of growth of mulberry trees. The microbial biomass and dehydrogenase activity in the soil

Table 1. The soil agrochemical and biological indicators, average 2016-2017

\begin{tabular}{|c|c|c|c|c|c|c|}
\hline \multirow{2}{*}{$\begin{array}{l}\text { Time of soil } \\
\text { samples }\end{array}$} & \multicolumn{6}{|c|}{ Soil agrochemical and biological indicators } \\
\hline & $\mathrm{pH}_{\mathrm{KCl}}$ & $\begin{array}{c}\text { Nitrogen, } \\
\%\end{array}$ & $\begin{array}{c}\mathrm{P}_{2} \mathrm{O}_{5} \\
\mathrm{mg} \mathrm{kg}^{-1}\end{array}$ & $\begin{array}{c}\mathrm{K}_{2} \mathrm{O}_{5} \\
\mathrm{mg} \mathrm{kg}^{-1}\end{array}$ & $\begin{array}{l}\text { Soil microbial biomass } \mathrm{C} \text {, } \\
\mu \mathrm{g} \mathrm{C} \mathrm{g}^{-1}\end{array}$ & $\begin{array}{l}\text { Soil dehydrogenase, } \\
\text { activity, } \mu \mathrm{g} \mathrm{g}^{-1}\end{array}$ \\
\hline May & $6.41^{\mathrm{A}}$ & $0.164^{\mathrm{A}}$ & $165^{\mathrm{A}}$ & $264^{\mathrm{A}}$ & $412^{\mathrm{A}}$ & $39^{\mathrm{A}}$ \\
\hline September & $6.81^{\mathrm{A}}$ & $0.151^{\mathrm{B}}$ & $124^{\mathrm{B}}$ & $198^{\mathrm{B}}$ & $328^{\mathrm{B}}$ & $32^{\mathrm{B}}$ \\
\hline
\end{tabular}

Different capital letters (A and B) in the same column represent significant differences between treatments, at $p<0.05$. 
significantly decreased, by 20.39 and $17.95 \%$, respectively, compared with that taken in May.

\section{Content of macroelements in white mulberry leaves}

The imbalance of essential elements disturbs normal biochemical functions of the body, which may lead to several pathological conditions (Bordoloi et al., 2016). In this study, all of the macronutritive elements showed variation between the leaves of the two mulberry cultivars dependent upon the harvest time.

Mulberry is a good source of minerals and provides nutritionally useful amounts of most of them, including calcium $(\mathrm{Ca})$, potassium $(\mathrm{K})$, phosphorus $(\mathrm{P})$, magnesium $(\mathrm{Mg})$ and sulphur $(\mathrm{S})$. Elements, such as $\mathrm{Ca}, \mathrm{K}, \mathrm{P}, \mathrm{Mg}$ and $\mathrm{S}$, in the leaves of the two different cultivars of white mulberry are depicted in Table 2.

$\mathrm{Ca}$ is an essential element responsible for bone strength and regulation of numerous functions in cells and tissues, such as muscle contraction, exocytosis and dental care prevention of colon cancer and reduction of obesity (Bronner, Pansu, 1998).

The results showed that the dominant macroelement in the leaves was $\mathrm{Ca}$. According to the mean results of our experiment, the harvest time had a significant effect on the Ca content in mulberry leaves. The Ca content was found to be significantly higher in the leaves of both cultivars in September. In this context, it is worth mentioning that the $\mathrm{Ca}$ content in the young 'Turchanka' and 'Plodovaja 3' leaves decreased significantly by 59.4 and $47.5 \%$, respectively, when harvested in June. The results are comparable to earlier reports. Noordulin et al. (2015) described that different mulberry genotypes and harvest time also influenced the calcium content. Other scientists have also confirmed the dependence of Ca levels on the characteristics of a cultivar (Radojković et al., 2014).

The increase of its content may be attributed to the deposition of $\mathrm{Ca}$ as calcium pectate in the middle lamella and the replacement of starch deposits by calcium oxalate crystals, which help sequester calcium in the leaves (Shear, Faust, 1980).

$\mathrm{K}$ is necessary for the formation of sugars, starches and carbohydrates and is important in protein synthesis and cell division in all parts of the plant. $\mathrm{K}$ is known as an activator of enzymes as well as a prominent factor in osmoregulation, which is important for the functions of enzymes and protein metabolism (Wayers, Paterson, 2001). It helps plants to adapt to unfavourable environmental conditions.

The results indicate that the $\mathrm{K}$ content in leaves from the two mulberry cultivars ranged from 1613

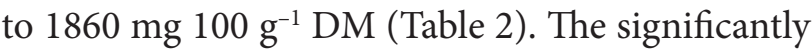
highest amount of $\mathrm{K}$ was found in the 'Plodovaja 3' leaves harvested in June. Imran et al. (2010) reported much lower amounts of this element in the Morus alba. In our investigation, the lowest content was determined in both cultivars harvested in September. A similar result was reported by Nooruldin et al. (2015), in which the K content in the leaves exhibited a decline with maturity. $\mathrm{He}$ found that the $\mathrm{K}$ content of mulberry leaves harvested from May to October was between 1306 and $1887 \mathrm{mg} 100 \mathrm{~g}^{-1} \mathrm{DM}$. As reported by many authors, chemical contents of plant leaves were influenced by many factors such as genetics, environment, climatic conditions, irrigation, fertilizing and soil conditions (Asrey et al., 2007; Chetri et al., 1999). Moreover, mineral contents in leaves change seasonally (Marschner, 1995). If it is presumed that characteristics such as the soil,

Table 2. The content of macroelements in white mulberry leaves, $\mathbf{m g} 100 \mathrm{~g}^{-1} \mathrm{DM}$, average 2016-2017

\begin{tabular}{cccccc|cc}
\hline \multirow{2}{*}{ Cultivar } & \multirow{2}{*}{ Harvest time } & \multicolumn{5}{c}{ Macroelements content } \\
\cline { 3 - 8 } & & $\mathrm{Ca}$ & $\mathrm{K}$ & $\mathbf{P}$ & $\mathbf{M g}$ & $\mathrm{S}$ \\
\hline 'Turchanka' & June & $1121^{\mathrm{C}}$ & $1681^{\mathrm{B}}$ & $379^{\mathrm{C}}$ & $232^{\mathrm{C}}$ & $50^{\mathrm{C}}$ \\
\hline & September & $2762^{\mathrm{A}}$ & $1675^{\mathrm{B}}$ & $693^{\mathrm{AB}}$ & $337^{\mathrm{A}}$ & $104^{\mathrm{A}}$ \\
\hline 'Plodovaja 3' & June & $1386^{\mathrm{B}}$ & $1860^{\mathrm{A}}$ & $637^{\mathrm{B}}$ & $216^{\mathrm{C}}$ & $73^{\mathrm{B}}$ \\
\hline & September & $2639^{\mathrm{A}}$ & $1613^{\mathrm{C}}$ & $702^{\mathrm{A}}$ & $275^{\mathrm{B}}$ & $80^{\mathrm{B}}$ \\
\hline
\end{tabular}

Different capital letters (A, B, and C) in the same column represent significant differences between treatments, at $p<0.05$. 
environment, climate factors and fertilizer application in the garden where all the trees were planted are homogenous, as reported earlier, these differences may be due to the genetic characteristics of the genotypes (Kazankaya et al., 2008).

$\mathrm{P}$ is necessary for photosynthesis, protein formation and almost all aspects of growth and metabolism in plants (Wayers, Paterson, 2001). Our findings show that the $\mathrm{P}$ contents in the leaves of the mulberry cultivars varied from 379 to $702 \mathrm{mg}$ $100 \mathrm{~g}^{-1} \mathrm{DM}$ (Table 2). A significantly lower P con-

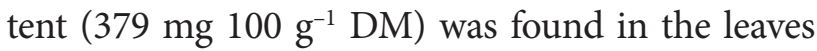
of the 'Turchanka' harvested in June. The content of this mineral was significantly higher in 'Plodovaja 3' leaves harvested in September compared with those in June. However, the highest $\mathrm{P}$ content (693 mg $100 \mathrm{~g}^{-1} \mathrm{DM}$ ) in the 'Turchanka' leaves occurred in September. These differences between the cultivars could be associated with genetic differences. Nooruldin et al. (2015) reported that the $P$ content decreased significantly with maturity (150 to $261 \mathrm{mg} 100 \mathrm{~g}^{-1} \mathrm{DM}$ ), which is similar to the findings of Satpal et al. (2004), who reported a similar trend while working with the mulberry plant.

$\mathrm{Mg}$ is a critical structural component of the chlorophyll molecule and is necessary for the functioning of plant enzymes in the production of carbohydrates, sugars and fats (Weyers, Paterson, 2001).

Comparisons were also drawn between the results of the Mg content identified in the lyophilized mulberry leaf samples harvested over two months. The $\mathrm{Mg}$ content ranged from 232 to $337 \mathrm{mg} 100 \mathrm{~g}^{-1}$ in 'Turchanka', while in 'Plodovaja 3' it ranged from 216 to $275 \mathrm{mg}^{100 \mathrm{~g}^{-1}}$ (Table 2). The Mg content in 'Turchanka' and 'Plodovaja 3' significantly increased by $31.2 \%$ and $21.3 \%$, respectively, with maturity, from June until September. Similar observations were reported by Nooruldin et al. (2015). They discovered that the Mg content significantly increased with maturity. According to Radojković et al. (2014), the first macroelement found in the extract of the M. alba and M. nigra leaves was $\mathrm{Mg}$ and the second was $\mathrm{Ca}$. The increasing trend of $\mathrm{Ca}$ and $\mathrm{Mg}$ with the age of the leaf could be attributed to a limited mobility of these elements in the phloem (Leece, Gilmour, 1974).

S-containing amino acids, cystine, cysteine and methionine, are of great significance in the struc- ture and function of proteins and enzymes. One of the most important S-containing peptides is glutathione, which has many important functions in plants and animals, including protection against oxidative stress (Malhotra, 1998).

Our findings show that the maximum $S$ content was recorded in both cultivars during September. The amount of this element was significantly higher in 'Turchanka' leaves (104 mg $100 \mathrm{~g}^{-1} \mathrm{DM}$ ) compared with that of 'Plodovaja 3' leaves ( $80 \mathrm{mg}$ $\left.100 \mathrm{~g}^{-1} \mathrm{DM}\right)$. Several authors found greater variations in levels of nutrients in different mulberry cultivars, indicating strong genetically controlled traits (Nooruldin et al., 2015; Satpal et al., 2004). We can declare that the $\mathrm{S}$ content in the leaves exhibited decline with maturity, whereas the significantly lowest (50 mg $100 \mathrm{~g}^{-1} \mathrm{DM}$ ) amount of $\mathrm{S}$ was detected in the young leaves from 'Turchanka'.

The research results of this study enable a purposeful selection of the desirable macroelements according to the mulberry leaf harvest time.

\section{CONCLUSIONS}

1. A decreasing tendency for soil agrochemical indicators has been observed throughout the entire period of growth of mulberry trees. At the end of the vegetation period the contents of nitrogen, available phosphorus and available potassium significantly decreased by $7.93,24.85$ and $25 \%$, respectively, compared with that taken in May. At the end of the mulberry tree vegetation period the microbial biomass and dehydrogenase activity in the soil significantly decreased, by 20.39 and $17.95 \%$, respectively, compared with that taken in the beginning of the vegetation period.

2. The contents of calcium and phosphorus in the leaves of both white mulberry cultivars 'Turchanka' and 'Plodovaja 3' increased in the course of the growing season. The highest contents of calcium and phosphorus in leaves of both cultivars were determined at the end of the experiment, i.e. in September.

3. The significantly highest amount of $\mathrm{K}$ (1860 mg $100 \mathrm{~g}^{-1} \mathrm{DM}$ ) was found in the 'Plodovaja 3' leaves harvested in June.

4 . The significantly highest contents of magnesium (337 mg $100 \mathrm{~g}^{-1} \mathrm{DM}$ ) and sulphur (104 mg $100 \mathrm{~g}^{-1} \mathrm{DM}$ ) were determined in the leaves of 
'Turchanka' at the end of the growing season, in September.

Received 8 October 2018

Accepted 12 December 2018

\section{REFERENCES}

1. Asrey R., Pal R. K., Sagar V. R., Patel V. B. 2007. Impact of tree age and canopy position on fruit quality of guava. Acta Horticulturae. Vol. 735. P. 259262.

2. Bordoloi M., Bordoloi P. K., Dutta P. P., Singh V., Nath., Narzary B., Barua I. C. 2016. Studies on some edible herbs: antioxidant activity, phenolic content, mineral content and antifungal properties. Journal of Functional Foods. Vol. 23. P. 220-229.

3. Bronner F., Pansu D. 1998. Nutritional aspects of calcium absorption. The Journal of Nutrition. Vol. 129. P. 9-12.

4. Butt M. S., Nazir A., Sultan T. M., Schroën K. 2008. Morus alba L. nature's functional tonic. Trends in Food Science \& Technology. Vol. 19. P. 505-512.

5. Chetri K., Sanyal D., Kar P. L. 1999. Changes in nutrient element composition of guava leaves in relation to season, cultivar, direction of shoot, and zone of leaf sampling. Communications in Soil Science and Plant Analysis. Vol. 30. P. 121-128.

6. Ercisli S., Orhan E. 2007. Chemical composition of white (Morus alba L.), red (Morus rubra L.) and black (Morus nigra L.) mulberry fruits. Food Chemistry. Vol. 103. P. 1380-1384.

7. Imran M., Khan H., Shah M., Khan R., Khan F. 2010. Chemical composition and antioxidant activity of certain Morus species. Journal of Zhejiang University Science B. Vol. 11. P. 973-980.

8. ISO 14240-2:1997. Soil quality - Determination of soil microbial biomass - Part 2: Fumigationextraction method.

9. ISO/FDIS 23753-2. Soil quality - Determination of dehydrogenase activity in soils - Part 2: Method using iodotetrazolium chloride (INT).

10. Jeszka-Skowron M., Flaczyk E., Podgórski T. 2017. In vitro and in vivo analyses of Morus alba Polish var. wielkolistna zolwinska leaf ethanol-water extract-antioxidant and hypocholesterolemic activities in hyperlipideamic rats. European Journal of Lipid Science and Technology. Vol. 119. 1600514. DOI: https://doi.org/10.1002/ejlt.201600514

11. Järvan M., Edesi L., Adamson A., Võsa T. 2014. Soil microbial communities and dehydrogenase activity depending on farming systems. Plant and Soil Environment. Vol. 60(10). P. 459-463.

12. Kazankaya A., Balta F., Öztürk N., Sönmez F. 2008. Mineral composition of pistachio (Pistacia vera L.) from Siirt, Turkey. Asian Journal of Chemistry. Vol. 20. P. 2337-2343.
13. Kim D., Kang Y., Jin W., Sung Y., Choi G., Kim H. 2014. Antioxidant activities and polyphenol content of Morus alba leaf extracts collected from varying regions. Biomedical Reports. Vol. 2. P. 675-680.

14. Leece D. R., Gilmour A. R. 1974. Diagnostic leaf analysis for stone fruit. 2. Seasonal changes in the leaf composition of peach. Australian Journal of Experimental Agriculture. Vol. 14. P. 822-827.

15. Levickiene D., Jariene E., Gajewski M., Danilčenko H., Vaitkevičiene N., Przybył J. L., Sitarek M. 2017. Influence of harvest time on biologically active compounds and the antioxidant activity in leaves of mulberry grown in Lithuania. Notulae Botanicae Horti Agrobotanici Cluj-Napoca. Vol. 45. P. 431-436. DOI: https://doi.org/10.15835/ nbha45210779

16. LST ISO 10390:2005. Soil quality - Determination of $p H$. Lithuanian Organization for Standardization.

17. Malhotra V. K. 1998. Biochemistry for Students. 10th edn. New Delhi: Jaypee Brothers Medical Publishers (P) Ltd.

18. Marschner H. 1995. Mineral Nutrition of Higher Plants. 2nd edn. San Diego: Academic Press İnc.

19. Nooruldin S., Kamili S., Mir M. R., Wani A., Malik G. N., Raja A., Bilal S. 2015. Seasonal variation in macro nutrient contents of mulberry (Morus alba) leaves under temperate climatic conditions of Kashmir. International Journal of Agriculture Innovations and Research. Vol. 4. P. 147-152.

20. Radojković M. M., Zeković Z. P., Dojinović B. P., Stojanović Z. S., Cvetanović A. D., Manojlović D. D. 2014. Characterization of Morus species in respect to micro, macro, and toxic elements. Acta Periodica Technologica. Vol. 45. P. 229-237.

21. Satpal B., Dal S., Bhatia S. K., Sharma J. R. 2004. Studies on the seasonal variation in macronutrient content of mulberry (Morus alba) leaves. Haryana Journal of Horticultural Sciences. Vol. 33. P. 34-36.

22. Shear C. B., Faust M. 1980. Nutritional ranges in deciduous tree fruits and nuts. Horticulture Reviews. Vol. 2. P. 142-163.

23. Srivastava S., Kapoor R., Thathola A., Srivastava R. P. 2006. Nutritional quality of leaves of some genotypes of mulberry (Morus alba). International Journal of Food Sciences and Nutrition. Vol. 57(5-6). P. 305-313.

24. Tabatabai M. A. 1982. Soil enzymes. In: Page A. L., Miller R. H., Keeney D. R. (eds.). Methods of Soil Analysis, Part 2. Madison: American Society of Agronomy and Soil Science Society of America.

25. Weyers J. D. B., Paterson N. W. 2001. Plant hormones and the control of physiological processes. New Phytologist. Vol. 15. P. 375-407.

26. Yang X. L., Yang L., Zheng H. Y. 2010. Hypolipidemic and antioxidant effects of mulberry (Morus alba L.) fruit in hyperlipidaemia rats. Food and Chemical Toxicology. Vol. 48. P. 2374-2379. 
Dovilè Levickiené, Nijolè Vaitkevičienė, Elvyra Jariené, Romas Mažeika

\section{MAKROELEMENTŲ KIEKIS BALTOJO ŠILKMEDŽIO (MORUS ALBA L.) LAPUOSE}

\section{Santrauka}

Tyrimo tikslas - ịvertinti dirvožemio agrocheminius ir biologinius kokybès rodiklius bei nustatyti baltojo šilkmedžio veislių 'Turchanka' ir 'Plodovaja 3' lapuose makroelementų sudèties ịvairavimą vegetacijos metu.

Lauko eksperimentas vykdytas Kauno rajone esančiame ekologiniame šilkmedyne 2016-2017 metais. Dirvožemio agrocheminėms bei biologinėms savybėms nustatyti mėginiai buvo sudaryti gegužès ir rugsèjo mẻn. (II-ąją dekadą), o baltojo šilkmedžio lapai makroelementų kiekybinei analizei buvo rinkti birželio ir rugsèjo mèn. (II-ąją dekadą). Eksperimento rezultatai parodè, kad dirvožemio agrocheminių rodikliu kiekio mažèjimo tendencija pastebèta per visą baltụjų šilkmedžiu vegetacijos laikotarpị. Baigiantis vegetacijai, rugsèjo mèn., azoto, judriojo fosforo ir judriojo kalio kiekiai dirvožemyje, kuriame augo 'Turčianka' ir 'Plodovaja 3' veislès baltieji šilkmedžiai, sumažèjo atitinkamai 7,93; 24,85 ir $25 \%$, palyginti su vegetacijos pradžios (gegužès mẻn.) dirvožemio tyrimų rezultatais. Dirvožemio, kuriame augo 'Turčianka' ir 'Plodovaja 3' veislès baltieji šilkmedžiai, mikroorganizmų biomasès sankaupos ir dehidrogenazès aktyvumas esmingai sumažéjo atitinkamai 20,39 ir 17,95 \%, palyginti su vegetacijos laikotarpio pradžia. Tyrimų rezultatai parodè, kad, priklausomai nuo skynimo laiko, abiejų veislių lapuose visos vegetacijos metu dominavo makroelementas kalcis. Makroelementų (kalcio, fosforo, mangano, sieros) kiekiai šilkmedžių veislių 'Turčianka' ir 'Plodovaja 3' lapuose per visą vegetaciją didèjo. Didžiausi $\mathrm{Ca}, \mathrm{Mg}, \mathrm{P}$ ir S kiekiai nustatyti rugsèjo mèn. skintuose veislès 'Turčianka' lapuose. Patikimai didžiausias kalio kiekis (1860 mg $100 \mathrm{~g}^{-1}$ s. m.) nustatytas birželio mèn. skintuose 'Plodovaja 3' veislès lapuose.

Gauti rezultatai gali padèti ūkininkams pasirinkti vertingesnę šilkmedžių veislę ir tinkamą lapų skynimo laiką. Lapai, surinkti iš Lietuvoje auginamų šilkmedžio augalų plantacijų, gali būti naudojami kaip maisto papildas, taip pat kaip natūralūs spalvos, skonio stiprikliai maisto produktų sudéčiai, funkcionalumui ir kokybei pagerinti.

Raktažodžiai: baltasis šilkmedis, lapai, makroelementai, skynimo laikas 